\title{
Biochemical Basis of Resistance against Mites in Table Grape Genotypes
}

\author{
Mantu Choudhury ${ }^{1 *}$, A.M. Nadaf ${ }^{1}$, M.M. Vinaykumar ${ }^{1}$, D.R. Patil ${ }^{2}$, \\ Mallikarjun Awati ${ }^{3}$ and D.A. Peerjade ${ }^{4}$ \\ ${ }^{1}$ Deparment of Entomology, College of Horticulture, University of Horticultural Sciences, \\ Bagalkot- 587104, Karnataka, India \\ ${ }^{2}$ Deparment of Fruit Science, College of Horticulture, University of Horticultural Sciences, \\ Bagalkot-587104, Karnataka, India \\ ${ }^{3}$ Deparment of Crop Improvement and Biotechnology, College of Horticulture, University of \\ Horticultural Sciences, Bagalkot- 587104, Karnataka, India \\ ${ }^{4}$ Deparment of Crop Improvement and Biotechnology, Horticulture Research and Extension \\ Station, Tidagundi, University of Horticultural Sciences, Vijayapur- 586119, Karnataka, India \\ *Corresponding author
}

\section{A B S T R A C T}

Keywords

Table grape

genotypes, Mites,

Sugar, Phenol, Amino acid and Tannin

Article Info

Accepted: 07 March 2018 Available Online: 10 April 2018
An investigation was carried out for evaluating the table grape genotypes against incidence of mites in Sector No. 70, UHS, Bagalkot, Karnataka after fore pruning (October) 2016 at different phenological stages. Results revealed that among 12 grape genotypes studied, significantly lowest mites population was recorded in Red Globe (T12) (8.63 mites/sq. inch of leaf) after 115 DAP. Significantly the highest population of mites was recorded in Fantasy Seedless (T10) (14.48 mites/sq. inch of leaf) after 115 DAP. Correlation studies revealed that the incidence of mites per sq. inch of leaf was significant and high positively correlated with sugar and amino acid. The incidence of mites per sq. inch of leaf was significant and high negatively correlated with phenol and tannin.

\section{Introduction}

Grape (Vitis vinifera L.) belonging to the Vitaceae family, originated in Western Asia and Europe. It was introduced to India from Iran and Afghanistan by the Persian invaders in $1300 \mathrm{AD}$ (Bose et al., 1999). The fresh grape berries are good source of sugars, carbohydrates, vitamins, proteins and minerals. Fruits are used for table purpose, wine, juice, raisins and canning. Fresh and dried fruits have various uses in Ayurveda and Umami medicine (Dry et al., 2004). The fruits are considered to be laxative, stomachic, diuretic and cooling agents. The juice of unripe berries is used as an astringent in throat infections. Tannins can also be extracted as a by-product from wine industry. It is an 
important fruit crop, earning foreign exchange. Grapes can be eaten as fresh or used for making jam, juice, jelly, vinegar, wine, grape seed extracts and grape seed oil. Approximately 71 per cent of world grape production is used for wine, 27 per cent as fresh fruit, and 2 per cent as dried fruit. However, in India, 90 per cent of the grape is used for table purpose, even though wine making has made strides. The rest of the grapes are used mostly for raisin (Nimbalkar et al., 2013). It is widely grown in France, Italy, America, Africa, Australia, Algeria and India. The major grape growing states in India are Maharashtra (56.9\%), Karnataka (21.8\%), Andhra Pradesh (1.52\%), Mizoram (3.05\%) and Tamil Nadu (2.99\%) accounting nearly 90 per cent of the total production (Anon., 2016). In India, the current area and production under grapes is estimated as 121000 hectare with an annual production of 2597000 tonnes and productivity 27.9 tonnes per hectare. Maharashtra accounts for more than 80 per cent of the production and Karnataka stands second with area 21760 hectare and production of 420810 tonnes. Vijayapur is one of the major districts of Karnataka with area 8670 hectare and production 102790 tonnes in grape cultivation (Anon., 2016).

Extensive and intensive cultivation of grapes tend to attract various kinds of pests to the vineyards (Alexandri, 1973). Bournier (1977) listed 132 insects that are known to attack grape vine in the world. In India as many as 60 species of insects and a few mites have been found damaging vines (Wadhi and Batra, 1964). According to Butani (1979) over 85 species of insects are known to occur on grapes in India. Balikai and Kotikal (2003) recorded as many as 26 pests infesting grapevine in Northern Karnataka. Among various arthropod pests, red spider mites cause considerable damage to the grapes.Six species of mites viz., Tetranychus urticae Koch, T. cinnabarinus Boisdual, T. neocaledonicus
Andre, Oligonicus mangiferus Rahmen and Sapra, O. punicae Baker and Eutetranychus orientalis Klein are found causing damage to grapevine in India. Out of these, the infestation of $T$. urticaeis reported to be quite considerable in abundance and damage designating it as an emerging sucking pest of grape these days (Anon., 2008). Red spider mite, $T$. urticae (Trombidiformes: Tetranychidae) suck sap from leaves thereby reducing berry weight and sugar development (Yadav et al., 2012). Among the biochemical constituents sugar, phenol, amino acid and tannin are responsible characters for incidence of sucking pests in different crops. However, information pertaining to varietal study, identification of possible biochemical traits as sources of resistance against incidence of mites on grapes is scanty. Keeping these points in view, the present investigation was undertaken to generate information on identification of mites resistance sources in grapes.

\section{Materials and Methods}

The experiment on biochemical basis of resistance against mites in grapes was conducted at Sector No. 70, UHS, Bagalkot during fore pruning 2016. Bagalkot is situated in northern dry zone of Karnataka state at $16.18^{\circ} \mathrm{N}$ latitude, $75.7^{\circ} \mathrm{E}$ longitude and at an altitude of $533 \mathrm{~m}$ above mean sea level; Bagalkot is considered to be a mild tropical region of Karnataka. The average rainfall of this area is about $683 \mathrm{~mm}$, distributed over a period of 4 months from June to September with 25 rainy days. The average annual temperature of this area is $25.8^{\circ} \mathrm{C}$.

After fore pruning the observations for mite population in grape genotypes were recorded at different phenological stages of crop. Randomized Block Design was followed for recording the observations. Five leaves were collected from each vine, brought to 
laboratory and observed under 7x magnifier hand lens. This procedure was repeated for five randomly selected and tagged vines for each genotype. The healthy leaf samples were collected simultaneously along with recording of mites in grapes and analyzed separately for different biochemical constituents like sugar (Dubois et al., 1956), phenol (Malick and Singh, 1980), amino acid (Moore and Stein, 1958) and tannin (Burns, 1971) by following standard procedures. The leaves were sampled from the corresponding vines in the early morning hours i.e. before $09.00 \mathrm{AM}$ and subjected to biochemical analysis. The biochemical traits of tested genotypes of grape were analysed through one way ANOVA technique. An attempt was also made to correlate the biochemical traits with incidence of mites on different genotypes using statistic $\mathrm{XL}$ analysis tool. The treatment means were separated by using DMRT.

\section{Results and Discussion}

\section{Incidence of mites on different grape genotypes}

The incidence of mites started on grape genotypes after 57 DAP which continued till harvest (115 DAP) and the results are presented in Table 1.

The mite population on leaves after 57 DAP in 12 different grape genotypes ranged from 3.11 to 9.16 mites per sq. inch of leaf. Significantly the lowest mite population was recorded in Red Globe (T12) (3.11mites/sq. inch of leaf). The next best genotypes are Manjari Naveen (T2) (4.10mites/sq. inch of leaf) on par with Krishna Sharad (T9) (4.58mites/sq. inch of leaf. Significantly the highest population of mites was recorded in Fantasy Seedless (T10) (9.16mites/sq. inch of leaf) on par with Kishmish Rozavis white (T4) (8.88mites/sq. inch of leaf) and Manik Chaman (T5) (8.63mites/sq. inch of leaf).
The mite population on leaves after 64 DAP in 12 different grape genotypes ranged from 4.03 to 10.16 mites per sq. inch of leaf. Significantly the lowest mite population was recorded in Red Globe (T12) (4.03mites/sq. inch of leaf) on par with Krishna Sharad (T9) (4.70mites/sq. inch of leaf. The next best genotypes are Sharad Seedless (T8) (5.86mites/sq. inch of leaf) on par with Manjari Naveen (T2) (6.25mites/sq. inch of leaf) and 2A Clone (T3) (6.42 mites/sq. inch of leaf).

Significantly the highest population of mites was recorded in Fantasy Seedless (T10) (10.16mites/sq. inch of leaf) on par with Kishmish Rozavis white (T4) (9.66mites/sq. inch of leaf) and Manik Chaman (T5) (9.34mites/sq. inch of leaf).

The mite population on leaves after 71 DAP in 12 different grape genotypes ranged from 3.22 to 9.80 mites per sq. inch of leaf. Significantly the lowest mite population was recorded in Red Globe (T12) (3.22mites/sq. inch of leaf). The next best genotypes are Krishna Sharad (T9) (4.48mites/sq. inch of leaf), Sharad Seedless (T8) (5.35mites/sq. inch of leaf) on par with Manjari Naveen (T2) (5.42mites/sq. inch of leaf). Significantly the highest population of mites was recorded in Fantasy Seedless (T10) (9.80mites/sq. inch of leaf) on par with Kishmish Rozavis white (T4) (9.63mites/sq. inch of leaf) and Manik Chaman (T5) (9.43mites/sq. inch of leaf).

The mite population on leaves after 85 DAP in 12 different grape genotypes ranged from 4.63 to 11.22 mites per sq. inch of leaf. Significantly the lowest mite population was recorded in Red Globe (T12) (4.63mites/sq. inch of leaf). The next best genotypes are Krishna Sharad (T9) (5.93mites/sq. inch of leaf), Manjari Naveen (T2) (7.38mites/sq. inch of leaf) on par with Sharad Seedless (T8) (7.52mites/sq. inch of leaf). 
Fig.1 Incidence of mites on different grape genotypes during fore pruning 2016

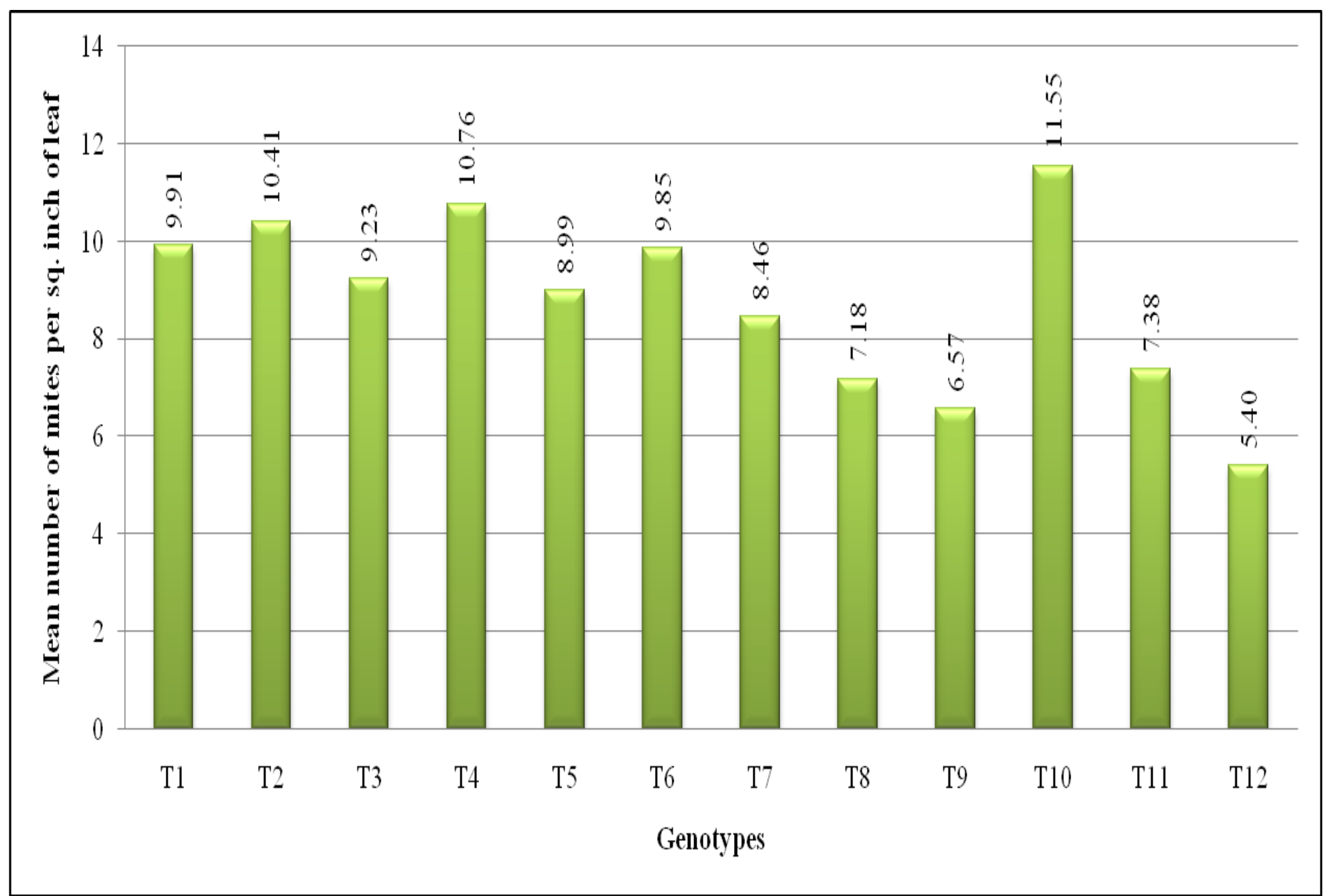

T1-Thompson Seedless, T2-Manjari Naveen, T3-2A Clone, T4-Kishmish Rozavis white, T5-Manik Chaman, T6-Sonaka, T7-Flame Seedless, T8-Sharad Seedless, T9-Krishna Sharad, T10-Fantasy Seedless, T11-Crimson Seedless, T12-Red Globe 
Table.1 Incidence of mites on different grape genotypes during fore pruning 2016

\begin{tabular}{|c|c|c|c|c|c|c|c|c|c|}
\hline \multirow[t]{3}{*}{ Sl. No. } & \multirow[t]{3}{*}{ Genotypes } & \multicolumn{7}{|c|}{ Number of mites per sq. inch of leaf } & \multirow[t]{3}{*}{ Mean } \\
\hline & & \multicolumn{7}{|c|}{ Days after pruning } & \\
\hline & & 57 DAP & 64 DAP & 71 DAP & 85 DAP & 92DAP & 99 DAP & 115 DAP & \\
\hline $\mathbf{T 1}$ & Thompson Seedless & $\begin{array}{c}7.50 \\
(2.83)^{\mathrm{d}}\end{array}$ & $\begin{array}{c}8.72 \\
(3.04)^{d}\end{array}$ & $\begin{array}{c}7.49 \\
(2.83)^{\mathrm{e}}\end{array}$ & $\begin{array}{c}10.25 \\
(3.28)^{\text {ef }}\end{array}$ & $\begin{array}{c}10.78 \\
(3.36)^{\text {ef }}\end{array}$ & $\begin{array}{c}11.81 \\
(3.51)^{\mathrm{de}}\end{array}$ & $\begin{array}{c}12.86 \\
(3.66)^{\text {fg }}\end{array}$ & 9.91 \\
\hline $\mathbf{T 2}$ & Manjri Naveen & $\begin{array}{c}4.10 \\
(2.15)^{b}\end{array}$ & $\begin{array}{c}6.25 \\
(2.60)^{\mathrm{bc}}\end{array}$ & $\begin{array}{c}5.42 \\
(2.43)^{\mathrm{c}}\end{array}$ & $\begin{array}{c}7.38 \\
(2.81)^{\mathrm{c}}\end{array}$ & $\begin{array}{c}7.64 \\
(2.85)^{b}\end{array}$ & $\begin{array}{c}9.16 \\
(3.11)^{\mathrm{ab}}\end{array}$ & $\begin{array}{c}10.29 \\
(3.29)^{\mathrm{bc}}\end{array}$ & 7.18 \\
\hline T3 & 2A Clone & $\begin{array}{c}6.66 \\
(2.68)^{d}\end{array}$ & $\begin{array}{c}6.42 \\
(2.63)^{b c}\end{array}$ & $\begin{array}{c}8.76 \\
(3.04)^{f}\end{array}$ & $\begin{array}{c}10.50 \\
(3.32)^{\text {fgh }}\end{array}$ & $\begin{array}{c}10.38 \\
(3.30)^{\text {ef }}\end{array}$ & $\begin{array}{c}10.46 \\
(3.31)^{\mathrm{cd}}\end{array}$ & $\begin{array}{c}11.41 \\
(3.45)^{\text {cde }}\end{array}$ & 9.23 \\
\hline $\mathrm{T4}$ & KishmishRozavis white & $\begin{array}{c}8.88 \\
(3.06)^{\mathrm{e}}\end{array}$ & $\begin{array}{c}9.66 \\
(3.19)^{\mathrm{de}}\end{array}$ & $\begin{array}{c}9.63 \\
(3.18)^{\mathrm{g}}\end{array}$ & $\begin{array}{c}11.09 \\
(3.40)^{\mathrm{gh}}\end{array}$ & $\begin{array}{c}11.41 \\
(3.45)^{\mathrm{f}}\end{array}$ & $\begin{array}{c}11.92 \\
(3.52)^{\mathrm{e}}\end{array}$ & $\begin{array}{c}12.75 \\
(3.64)^{\mathrm{efg}}\end{array}$ & 10.76 \\
\hline T5 & ManikChaman & $\begin{array}{c}8.63 \\
(3.02)^{\mathrm{e}}\end{array}$ & $\begin{array}{c}9.34 \\
(3.14)^{\mathrm{de}}\end{array}$ & $\begin{array}{c}9.43 \\
(3.15)^{\mathrm{g}}\end{array}$ & $\begin{array}{c}10.49 \\
(3.31)^{\text {fgh }}\end{array}$ & $\begin{array}{c}11.09 \\
(3.40)^{f}\end{array}$ & $\begin{array}{c}11.45 \\
(3.46)^{\mathrm{de}}\end{array}$ & $\begin{array}{c}12.44 \\
(3.60)^{\text {ef }}\end{array}$ & 10.41 \\
\hline T6 & Sonaka & $\begin{array}{c}7.52 \\
(2.83)^{d}\end{array}$ & $\begin{array}{c}8.80 \\
(3.05)^{d}\end{array}$ & $\begin{array}{c}8.72 \\
(3.04)^{\mathrm{f}}\end{array}$ & $\begin{array}{c}10.35 \\
(3.29)^{\mathrm{efg}}\end{array}$ & $\begin{array}{c}10.80 \\
(3.36)^{\text {ef }}\end{array}$ & $\begin{array}{c}10.65 \\
(3.34)^{\text {cde }}\end{array}$ & $\begin{array}{c}12.14 \\
(3.56)^{\mathrm{ef}}\end{array}$ & 9.85 \\
\hline $\mathrm{T7}$ & Flame Seedless & $\begin{array}{c}5.37 \\
(2.42)^{c}\end{array}$ & $\begin{array}{c}8.72 \\
(3.04)^{d}\end{array}$ & $\begin{array}{c}7.70 \\
(2.86)^{\mathrm{e}}\end{array}$ & $\begin{array}{c}9.62 \\
(3.18)^{\mathrm{e}}\end{array}$ & $\begin{array}{c}9.95 \\
(3.23)^{\mathrm{de}}\end{array}$ & $\begin{array}{c}10.52 \\
(3.32)^{\text {cde }}\end{array}$ & $\begin{array}{c}11.08 \\
(3.40)^{\mathrm{bcd}}\end{array}$ & 8.99 \\
\hline T8 & Sharad Seedless & $\begin{array}{c}5.43 \\
(2.43)^{c}\end{array}$ & $\begin{array}{c}5.84 \\
(2.52)^{b}\end{array}$ & $\begin{array}{c}5.35 \\
(2.42)^{c}\end{array}$ & $\begin{array}{c}7.52 \\
(2.83)^{c}\end{array}$ & $\begin{array}{c}8.28 \\
(2.96)^{b c}\end{array}$ & $\begin{array}{c}9.35 \\
(3.14)^{\mathrm{abc}}\end{array}$ & $\begin{array}{c}9.88 \\
(3.22)^{\mathrm{abc}}\end{array}$ & 7.38 \\
\hline T9 & Krishna Sharad & $\begin{array}{c}4.58 \\
(2.25)^{b}\end{array}$ & $\begin{array}{c}4.70 \\
(2.28)^{\mathrm{a}}\end{array}$ & $\begin{array}{c}4.48 \\
(2.23)^{b}\end{array}$ & $\begin{array}{c}5.93 \\
(2.53)^{b}\end{array}$ & $\begin{array}{c}7.92 \\
(2.90)^{b c}\end{array}$ & $\begin{array}{c}8.79 \\
(3.05)^{\mathrm{a}}\end{array}$ & $\begin{array}{c}9.59 \\
(3.18)^{\mathrm{ab}}\end{array}$ & 6.57 \\
\hline T10 & Fantasy Seedless & $\begin{array}{c}9.16 \\
(3.11)^{\mathrm{e}}\end{array}$ & $\begin{array}{c}10.16 \\
(3.27)^{\mathrm{e}}\end{array}$ & $\begin{array}{c}9.80 \\
(3.21)^{\mathrm{g}}\end{array}$ & $\begin{array}{c}11.22 \\
(3.42)^{\mathrm{h}}\end{array}$ & $\begin{array}{c}12.61 \\
(3.62)^{g}\end{array}$ & $\begin{array}{c}13.38 \\
(3.73)^{f}\end{array}$ & $\begin{array}{c}14.48 \\
(3.87)^{\mathrm{g}}\end{array}$ & 11.55 \\
\hline T11 & Crimson Seedless & $\begin{array}{c}6.71 \\
(2.69)^{d}\end{array}$ & $\begin{array}{c}7.04 \\
(2.75)^{c}\end{array}$ & $\begin{array}{c}6.86 \\
(2.71)^{d}\end{array}$ & $\begin{array}{c}8.46 \\
(2.99)^{\mathrm{d}}\end{array}$ & $\begin{array}{c}9.14 \\
(3.10)^{\mathrm{cd}}\end{array}$ & $\begin{array}{c}10.47 \\
(3.31)^{\mathrm{cd}}\end{array}$ & $\begin{array}{c}10.53 \\
(3.32)^{b c}\end{array}$ & 8.46 \\
\hline T12 & Red Globe & $\begin{array}{c}3.11 \\
(1.90)^{\mathrm{a}}\end{array}$ & $\begin{array}{c}4.03 \\
(2.13)^{\mathrm{a}}\end{array}$ & $\begin{array}{c}3.22 \\
(1.93)^{\mathrm{a}}\end{array}$ & $\begin{array}{c}4.63 \\
(2.26)^{\mathrm{a}}\end{array}$ & $\begin{array}{c}5.79 \\
(2.51)^{\mathrm{a}}\end{array}$ & $\begin{array}{c}8.37 \\
(2.98)^{\mathrm{a}}\end{array}$ & $\begin{array}{c}8.63 \\
(3.02)^{\mathrm{a}}\end{array}$ & 5.40 \\
\hline & S.Em \pm & 0.05 & 0.06 & 0.03 & 0.03 & 0.05 & 0.07 & 0.08 & \\
\hline & C.D. at $5 \%$ & 0.15 & 0.18 & 0.09 & 0.11 & 0.16 & 0.20 & 0.23 & \\
\hline & CV (\%) & 5.50 & 6.16 & 6.55 & 5.82 & 5.17 & 7.88 & 5.29 & \\
\hline
\end{tabular}

Each value is the mean of five replications

Figures in parenthesis indicate square root $(x+0.5)$ transformed values

Figures in each column followed by same alphabet $(\mathrm{s})$ are not significantly different $(\mathrm{P}=0.05)$ 
Table.2 Biochemical constituents in leaves 115 DAP of grape genotypes during Fore pruning 2016

\begin{tabular}{|c|c|c|c|c|c|c|}
\hline SI. No. & Genotypes & $\begin{array}{l}\text { Number of } \\
\text { mites per sq. } \\
\text { inch of leaf }\end{array}$ & $\begin{array}{l}\text { Sugar } \\
(\mathrm{mg} / \mathrm{g})\end{array}$ & $\begin{array}{l}\text { Phenol } \\
(\mathrm{mg} / \mathrm{g})\end{array}$ & $\begin{array}{l}\text { Amino acid } \\
(\mu \mathrm{g} / \mathrm{g})\end{array}$ & $\begin{array}{c}\text { Tannin } \\
(\mu \mathrm{g} / \mathrm{g})\end{array}$ \\
\hline $\mathrm{T} 1$ & Thompson Seedless & $\begin{array}{l}12.86 \\
(3.66)^{\mathrm{fg}}\end{array}$ & $2.14^{\mathrm{c}}$ & $4.39^{\mathrm{cd}}$ & $191.34^{d}$ & $142.86^{\mathrm{cd}}$ \\
\hline $\mathrm{T} 2$ & Manjri Naveen & $\begin{array}{c}10.29 \\
(3.29)^{\mathrm{bc}}\end{array}$ & $2.11^{\mathrm{bc}}$ & $4.59^{b}$ & $151.70^{\mathrm{bc}}$ & $160.50^{b}$ \\
\hline $\mathrm{T3}$ & 2A Clone & $\begin{array}{c}11.41 \\
(3.45)^{\text {cde }}\end{array}$ & $2.15^{\mathrm{c}}$ & $4.26^{\mathrm{d}}$ & $202.24^{\text {de }}$ & $140.04^{\mathrm{d}}$ \\
\hline $\mathrm{T4}$ & $\begin{array}{l}\text { KishmishRozavis } \\
\text { white }\end{array}$ & $\begin{array}{c}12.75 \\
(3.64)^{\text {efg }}\end{array}$ & $2.86^{\mathrm{f}}$ & $3.32^{\mathrm{f}}$ & $275.96^{\mathrm{g}}$ & $85.70^{\mathrm{g}}$ \\
\hline $\mathrm{T5}$ & ManikChaman & $\begin{array}{c}12.44 \\
(3.60)^{\text {ef }}\end{array}$ & $2.68^{\mathrm{e}}$ & $3.60^{\mathrm{e}}$ & $210.10^{\mathrm{ef}}$ & $106.46^{\mathrm{ef}}$ \\
\hline T6 & Sonaka & $\begin{array}{c}12.14 \\
(3.56)^{\mathrm{ef}}\end{array}$ & $2.28^{\mathrm{d}}$ & $3.63^{\mathrm{e}}$ & $197.06^{d}$ & $135.32^{\mathrm{d}}$ \\
\hline $\mathbf{T 7}$ & Flame Seedless & $\begin{array}{c}11.08 \\
(3.40)^{\mathrm{bcd}}\end{array}$ & $2.76^{\mathrm{ef}}$ & $4.35^{\mathrm{d}}$ & $218.76^{\mathrm{f}}$ & $95.84^{\mathrm{fg}}$ \\
\hline $\mathrm{T} 8$ & Sharad Seedless & $\begin{array}{c}9.88 \\
(3.22)^{\mathrm{abc}}\end{array}$ & $2.11^{\mathrm{bc}}$ & $4.52^{\mathrm{bc}}$ & $142.26^{b}$ & $159.66^{\mathrm{b}}$ \\
\hline T9 & Krishna Sharad & $\begin{array}{c}9.59 \\
(3.18)^{\mathrm{ab}}\end{array}$ & $2.01^{\mathrm{ab}}$ & $4.64^{\mathrm{ab}}$ & $161.86^{c}$ & $152.52^{\mathrm{bc}}$ \\
\hline T10 & Fantasy Seedless & $\begin{array}{l}14.48 \\
(3.87)^{\mathrm{g}}\end{array}$ & $3.08^{\mathrm{g}}$ & $2.80^{\mathrm{g}}$ & $327.92^{\mathrm{h}}$ & $67.86^{\mathrm{h}}$ \\
\hline T11 & Crimson Seedless & $\begin{array}{c}10.53 \\
(3.32)^{b c}\end{array}$ & $2.36^{\mathrm{d}}$ & $3.56^{\mathrm{e}}$ & $217.96^{\mathrm{f}}$ & $110.30^{\mathrm{e}}$ \\
\hline T12 & Red Globe & $\begin{array}{c}8.63 \\
(3.02)^{\mathrm{a}}\end{array}$ & $1.89^{\mathrm{a}}$ & $4.72^{\mathrm{a}}$ & $106.46^{\mathrm{a}}$ & $214.12^{\mathrm{a}}$ \\
\hline & S.Em \pm & 0.08 & 0.04 & 0.05 & 4.51 & 3.94 \\
\hline & C.D. at $5 \%$ & 0.23 & 0.12 & 0.14 & 12.87 & 11.25 \\
\hline & $\mathrm{CV}(\%)$ & 5.29 & 6.03 & 5.83 & 7.04 & 6.74 \\
\hline
\end{tabular}

Each value is the mean of five replications

Figures in each column followed by same alphabet ( $\mathrm{s})$ are not significantly different $(\mathrm{p}=0.05)$

Table.3 Correlation for number of mites per sq. inch of leaves with its components in grape genotypes after 115 days of fore pruning

\begin{tabular}{|l|c|c|c|c|c|}
\hline & Mites incidence & Sugar & Phenol & Amino acid & Tannin \\
\hline Mites incidence & $\mathbf{1}$ & & & & \\
\hline Sugar & $0.762 * *$ & $\mathbf{1}$ & & & \\
\hline Phenol & $-0.793 * *$ & $-0.821 * *$ & $\mathbf{1}$ & & \\
\hline Amino acid & $0.865 *$ & $0.908 * *$ & $-0.890^{* *}$ & $\mathbf{1}$ & \\
\hline Tannin & $-0.788^{* *}$ & $-0.930 * *$ & $0.818 * *$ & $-0.939 *$ & $\mathbf{1}$ \\
\hline
\end{tabular}

Critical r @ 1\%=0.325 Critical r @ 5\%=0.250*Significant at 5\%** Significant at 1\% 
Significantly the highest population of mites was recorded in Fantasy Seedless (T10) (11.22mites/sq. inch of leaf) on par with Kishmish Rozavis white (T4) (11.09 mites/sq. inch of leaf), 2A Clone (T3) (10.49 mites/sq. inch of leaf) and Manik Chaman (T5) (10.50mites/sq. inch of leaf).

The mite population on leaves after 92 DAP in 12 different grape genotypes ranged from 5.79 to 12.61 mites per sq. inch of leaf. Significantly the lowest mite population was recorded in Red Globe (T12) (5.79mites/sq. inch of leaf). The next best genotypes are Manjari Naveen (T2) (7.64mites/sq. inch of leaf) on par with Krishna Sharad (T9) (7.92mites/sq. inch of leaf), Sharad Seedless (T8) (8.28mites/sq. inch of leaf). Significantly the highest population of mites was recorded in Fantasy Seedless (T10) (12.61mites/sq. inch of leaf), followed by Kishmish Rozavis white (T4) (11.41 mites/sq. inch of leaf) on par with Manik Chaman (T5) (11.09mites/sq. inch of leaf).

The mite population on leaves after 99 DAP in 12 different grape genotypes ranged from 8.37 to 13.38 mites per sq. inch of leaf. Significantly the lowest mite population was recorded in Red Globe (T12) (8.37mites/sq. inch of leaf) on par with Krishna Sharad (T9) (8.79mites/sq. inch of leaf) and Manjari Naveen (T2) (9.16mites/sq. inch of leaf). Significantly the highest population of mites was recorded in Fantasy Seedless (T10) (13.38mites/sq. inch of leaf), followed by Kishmish Rozavis white (T4) (11.92 mites/sq. inch of leaf) on par with Manik Chaman (T5) (11.45mites/sq. inch of leaf), Sonaka (T6) (10.65mites/sq. inch of leaf) and Flame Seedless (T7) (10.52mites/sq. inch of leaf).

The mite population on leaves after 115 DAP in 12 different grape genotypes ranged from 8.63 to 14.48 mites per sq. inch of leaf. Significantly the lowest mite population was recorded in Red Globe (T12) (8.63mites/sq. inch of leaf) on par with Krishna Sharad (T9) (9.59mites/sq. inch of leaf) and Sharad Seedless (T8) (9.88mites/sq. inch of leaf). Significantly the highest population of mites was recorded in Fantasy Seedless (T10) (14.48mites/sq. inch of leaf) on par with Kishmish Rozavis white (T4) (12.75 mites/sq. inch of leaf) (Fig. 1).

The findings of the present study arealso in partial agreement with the findings of Khanjani et al., (2014) for Grape Erineum Mite. The lowest and highest mite densities were found on leaves of White Thompson Seedless and Gazne respectively.

\section{Biochemical constituents in different grape genotypes}

The incidence of mites started on grape genotypes after 57 DAP which continued till harvest (115 DAP). Among these period of investigation mite incidence was found highest during 115 DAP in all the genotypes. The biochemical constituents during this period are discussed here under.

The concentration of phenol and tannin was significantly the highest in Red Globe (T12) (4.72mg/g and $214.12 \mu \mathrm{g} / \mathrm{g}$ ), which supported the lowest 8.63 mites per sq. inch of leaf.

However, significantly the highest mites were recorded in Fantasy Seedless (T10) 14.48 mites per sq. inch of leaf this was due to highest sugar and amino acid $(3.81 \mathrm{mg} / \mathrm{g}$ of leaf and $370.40 \mu \mathrm{g} / \mathrm{g}$ of leaf respectively), also the lowest phenol and tannin $(1.89 \mathrm{mg} / \mathrm{g}$ of leaf and $47.6 \mu \mathrm{g} / \mathrm{g}$ of leaf respectively) (Table 2). This outcome is in close agreement with the findings of Roseleen and Ramaraju (2011) across the genotypes of okra and resistant wild type. Kasturi bhendi recorded the highest level of total phenols in healthy leaves by incidence of lowest mite population. 
Correlation coefficients between biochemical traits and incidence of mites in grape genotypes

The incidence of mites on grape genotypes were correlated with the biochemical traits like sugar, phenol, amino acid and tannin and presented in Table 3.

The incidence of mites was significant and positively correlated with amino acid ( $\mathrm{r}=$ $0.865)$, followed by sugar $(r=0.762)$. The incidence of mites was significant and negatively correlated with phenol $(\mathrm{r}=-0.793)$, followed by tannin $(r=-0.788)$.

The strong correlation was found between incidence of mites and biochemical traits of leaves in grape genotypes. Among the biochemical traits, sugar and amino acid in leaves exhibited significant positive correlation with incidence of mites, while phenol and tannin in leaves showed significant negative correlation.

\section{Acknowledgement}

The authors are thankful to Professor and Head, Department of Entomology, College of Horticulture, Bagalkot, Dean, College of Horticulture, Bagalkot as well as the Director of Research and Dean Post Graduate Studies, University of Horticultural Sciences, Bagalkot for providing all the necessary facilities during the course of the study.

\section{References}

Alexandri, A. A., 1973, Efficacy of some insecticides in the control of moth, Polychrosis botrana Schieff Rouman. Ann. Inst. Cerc. Penttu. Pl. Prot., 9: 507-514.

Anonymous, 2008, Management of mites on grapes, Extension Folder No.15, National Research Centre for Grapes, Pune, India.
Anonymous, 2016, Area and production 2014-15. IG printers Pvt. Ltd., 105, DSIDC, Okhla, phase I, New Delhi, pp. 21.

Balikai, R.A. and Kotikal, Y.K, 2003, Pest status of grapevine in northern Karnataka. Agric. Sci. Digest, 23(4): 276-278.

Bose, T.K., Mitra, S.K., Farooqi, A. A. and Sadhu, M. K., 1999, Grapes. Trop. Hort., Naya Prakash, Calcutta, India, pp. 259-268.

Bournier, A., 1977, Grape insects. Annu. Rev. Entomol., 22: 355-376.

Burns, R. E., 1971, Method for estimation for tannin in grain sorghum. Agron. J., 63: 511-512.

Butani, D.K., 1979, Insects and fruits. Periodical Export Book Agency, New Delhi, pp. 398.

Dry, P.R., Hand, P.G. and Ristic, R., 2004. What is Vine Balance? Proceedings of $12^{\text {th }}$ Australian Wine Industry Technical Conference, Melbourne, Victoria, Australia, 68-74.

Dubois, M., Gilles, K. A., Hamilton, J. K., Rebers, P. A. and Smith, F., 1956, Colorimetric method for determination of sugars and related substances. Anal. Chem., 28(3): 350-356.

http://www.NHBdatabase.com

Khanjani, M., Khederi, S. J. and Fayaz, B. A., 2014, Resistance of three grapevine cultivars to grape erineum mite, Colomerusvitis (Acari: Eriophyidae), in field conditions. Persian J. Acarol., 3(1): 63-75

Mallick, C. P. and Singh, M. B., 1980, Plant enzymology and histoenzymology, Kalyani publishers, New Delhi, pp. 286.

Moore, S. and Stein, W. H., 1958, A modified ninhydrin reagent for the photometric determination of amino acids and related compounds. J. Biol. Chem., 211: 907-913. 
Nimbalkar, S.S. and Bansode, P.S., 2013. Management of grapes export to UK and Netherland by Abhinav Drakasha Utpadak Sahakari Sanstha, Agar in Pune district. Agriculture Update, 8(3):371-377.

Roseleen, S. S. J. and Ramaraju, K., 2011, Resistance of okra against two-spotted spider mite, Tetranychus urticae Koch. Ann. Pl. Prot. Sci., 20(1): 126-129.

Wadhi, S.R. and Batra, H.N., 1964, Pests of tropical and subtropical fruit trees. In
Entomology in India, Ed. Pant, N.C., (A special number of the Indian Journal of Entomology), The Entomological Society of India, New Delhi, pp. 227260.

Yadav, D. S., Kamte, A. S. and Jadhav, R. S., 2012, Evaluation of cyantraniliprole for thrips and red spider mite management in table grapes. Pestic. Res. J., 24(2): 217-222.

\section{How to cite this article:}

Mantu Choudhury, A.M. Nadaf, M.M. Vinaykumar, D.R. Patil, Mallikarjun Awati and Peerjade, D.A. 2018. Biochemical Basis of Resistance against Mites in Table Grape Genotypes. Int.J.Curr.Microbiol.App.Sci. 7(04): 736-744. doi: https://doi.org/10.20546/ijcmas.2018.704.082 